\title{
Gas emission in the poultry production
}

Fernanda Campos de Sousa • Ilda de Fátima Ferreira Tinôco • Jadir Nogueira da Silva • Fátima de Jesus Fôlgoa Baptista • Cecília de Fátima Souza • Alex Lopes da Silva

FC Sousa (Corresponding author) • IFF Tinôco • JN Silva • CF Souza

Departamento de Engenharia Agrícola, Construções Rurais e Ambiência, AMBIAGRO, Universidade Federal de Viçosa (UFV), Viçosa, MG, Brazil.

email: fernanda.sousa@ufv.br

\section{FJF Baptista}

Departamento de Engenharia Rural, Escola de Ciências e Tecnologia, Universidade de Évora and Instituto de Ciências Agrárias e Ambientais Mediterrânicas, Évora, Portugal.

AL Silva

Departamento de Zootecnia, Universidade Federal de Viçosa (UFV), Viçosa, MG, Brazil.

Received: August 22, 2016 • Revised: December 14, 2016 • Accepted: December 15, 2016

Abstract Among the greenhouse gases produced in broiler chicken production environments, ammonia stands out for being present in higher concentrations and for significantly affecting human and animal health. Thus, this review evaluates the various sources of ammonia generation in animal production facilities, the damages caused by ammonia emissions in broiler chicken production facilities, and the accompanying economic losses. The main source of ammonia in broiler production is the nitrogen ingested in the diet, which is broken down into uric acid and, eventually, into ammonia that is volatilized from the bed to the environment. High ammonia concentrations in such facilities can affect productivity and result in economic losses. The effects on the environment are eutrophication of water bodies and ground water contamination. Ammonia emission control in poultry production facilities is therefore inevitable to avoid economic losses, prevent environmental damage, and increase feed efficiency.

Keywords: air quality, ammonia emission, broilers

\section{Introduction}

Intensive animal production in confinement, in particular in the case of poultry farming with the use of reused avian beds, is responsible for the emission of a significant amount of air pollutants. The most commonly emitted gases are carbon monoxide (CO), carbon dioxide $\left(\mathrm{CO}_{2}\right)$, and ammonia $\left(\mathrm{NH}_{3}\right)$, with $\mathrm{NH}_{3}$ being the main gas which negatively affects birds and workers (Angus et al., 2006) and is generally found in high concentrations in poultry farms (Owada et al 2007).

For more than a decade, the impacts of $\mathrm{NH}_{3}$ emissions on the environment have been the focus of research studies in several European countries and in North America (Faulkner and Shaw 2008; Mosquera et al 2005; Scholtens et al., 2004), where gas inventories have already been carried out and protocols to reduce ammonia emissions have been established. In these countries, studies evaluating pollutant emissions from animal production facilities can generally be performed relatively easily, since most of the facilities are closed and, therefore, control the volume of air in the coats (Osorio-Saraz et al 2014).

For regions with tropical and subtropical climates, such as Brazil, the determination of pollutant emissions from animal production is much more complex (Mendes et al 2014). This is mainly due to the fact that almost all animal production facilities in Brazil, as well as in other countries with a hot climate, are kept open for most of the time (Tinôco 2001), thus constituting open thermodynamic systems influenced by wind currents and other noncontrollable external factors, making it difficult to quantify emission levels (Saraz et al 2013).

For countries with hot climates, there are only a few studies on atmospheric pollutant emissions from food production; most of these studies have focused on animal farming in intensive breeding systems, as the amount of waste produced has become a serious issue in this industry. In this review, we have focused on ammonia emissions in animal production in order to evaluate the issues of high emissions in poultry production systems under tropical and subtropical climates. Such a review can also raise awareness of this problem and contribute to maintain environmental quality standards associated with the production of low-cost food, such as chicken, with the aim to increase food production sustainability.

For this, we searched the literature aiming to review the main sources of ammonia in animal production facilities, main damages caused by the emission of particulate pollutants in the poultry industry, specifically ammonia, and the resulting economic losses.

Main sources of ammonia emissions 
Agricultural activities, especially those that require confinement and therefore occur in agricultural facilities, generate waste accumulation and are therefore the main sources of ammonia $\left(\mathrm{NH}_{3}\right)$ emissions into the atmosphere. In the United States and Canada, agriculture accounts for $75 \%$ of ammonia emissions, with most of these emissions being generated by animal production (Bittman and Mikkelsen 2009; Fabbri et al 2007).

The production of broilers is among the main animal feedlot systems, especially in the Brazilian poultry industry, which is one of the largest producers of chicken meat in the world (Marangoni et al 2015). Feedlot systems are a costefficient form of animal production and characterized by relatively small production cycles, high technological levels, small production space, and the demand for fewer resources such as water and energy (Mendes et al 2015).

Since broiler chicken performance depends on the quality of the feed offered and rations with considerable energy and protein content are usually administered, the amount of nitrogen that meets the nutritional demands of the animals (Gay and Knowlton 2009) also makes the poultry feed the main source of nitrogen in the poultry waste (Mendes et al 2015).

Such considerable waste generation, coupled with a significant ammonia emission potential, can negatively affect the air quality in the facilities and surroundings of the animal production facility. Waste in the avian bed causes gas production inside the facility and is considered the main source of gas emissions (Nääs et al 2007), mainly because almost half of the amount of the nitrogen in the feed is retained as animal protein, the rest is excreted as waste (Pessôa et al 2012; Silva et al 2006). Of this, 35\% has potential for emission by being converted to ammoniacal nitrogen, given the ammonia emission factor of waste excreted by birds (Misselbrook et al 2000).

When ingested by animals, the amino acids, in the form of proteins, are adsorbed and are either converted into other amino acids or degraded to release energy. As poultry diets usually contain high amounts of protein, some of these proteins are still excreted in the undigested form, i.e., nitrogen that is not metabolized as protein is excreted directly and part of what has been digested results in release of uric acid; through microbial degradation, ammonia is released into the atmosphere (Gay and Knowlton 2009; Pessôa et al 2012).

Animals excrete nitrogen in the form of uric acid, urea and ammonia, and birds mainly excrete uric acid (Bittman and Mikkelsen 2009) which, when degraded, releases ammonium $\left(\mathrm{NH}_{4}^{+}\right)$, a dominant form of nitrogen in poultry waste. Under certain conditions, such as high moisture levels and increased $\mathrm{pH}$ values, ammonium is rapidly converted into ammonia $\left(\mathrm{NH}_{3}\right)$, an extremely volatile substance that negatively affects the quality of air inside the aviary (França et al 2014; Gay and Knowlton 2009; Oviedo-Rondón 2008). As mentioned before, ammonia volatilization is more common under alkaline conditions, with $\mathrm{pH}$ values around 9, coupled with high temperatures and increased ammonia concentrations in the waste (Bittman and Mikkelsen 2009). The degradation process of uric acid occurs according to Reaction 1:

$$
\mathrm{NH}_{4}^{+}+\mathrm{OH}^{-} \rightarrow \mathrm{NH}_{3}+\mathrm{H}_{2} \mathrm{O} \quad \text { Reaction } 1
$$

In summary, ammonia in broiler production environments is formed through chemical and microbial decomposition of uric acid excreted by birds. The decomposition process is carried out by urease, an enzyme produced by microorganisms, which catalyzes the hydrolysis of urea into ammonia and carbon dioxide in aqueous medium, allowing ammonia volatilization, defined as nitrogen losses to the atmosphere (Oliveira et al 2003). The decomposition of urea occurs according to Reaction 2:

$$
\left(\mathrm{NH}_{2}\right)_{2} \mathrm{CO}+\mathrm{H}_{2} \mathrm{O} \rightarrow 2 \mathrm{NH}_{3}+\mathrm{CO}_{2}^{\text {Reaction } 2}
$$

Five enzymatic steps are involved in the aerobic degradation of uric acid (Figure 1). First, uric acid $\left(\mathrm{C}_{5} \mathrm{H}_{4} \mathrm{~N}_{4} \mathrm{O}_{3}\right)$, the dominant form of nitrogen in the excreta, is converted into allantoin $\left(\mathrm{C}_{4} \mathrm{H}_{6} \mathrm{~N}_{4} \mathrm{O}_{3}\right)$ by the enzyme uricase. In the second step, allantoin is converted to allantoic acid by allantoinase. Subsequently, allantoic acid is converted to ureidoglycolate by allantoate amidohydrolase, and ureidoglycolate is then converted to glyoxylate and urea by ureidoglycolase. The last step consists of the hydrolysis of urea $\left(\left(\mathrm{NH}_{2}\right)_{2} \mathrm{CO}\right)$ into ammonia $\left(\mathrm{NH}_{3}\right)$ and $\mathrm{CO}_{2}$ by the enzyme urease (Groot Koerkamp et al 1998).

Effects and diseases caused by air pollutants

Reductions in particulate emissions from animal production facilities are of major importance because of their negative effects on animals and humans. There are associations between the particulate matter content in the air and respiratory and cardiovascular effects, even at relatively low levels. The size of the particle influences its deposit form in the respiratory tract; larger particles are usually filtered in the nose and throat, causing no serious problems, whereas smaller particles can reach the lungs and cause considerable health problems (Melse et al 2009).

The harmful effects of ammonia usually tend to be underestimated by producers, since human olfaction can easily detect concentrations above $5 \mathrm{ppm}$ in the environment (Ritz et al 2005). However, when exposure occurs for prolonged periods, this sensitivity is lost and can promote damages that are not perceived or identified in time (Egute et 
al 2010). High levels of ammonia in the environment negatively impact both the health and production of animals and workers (Gay and Knowlton 2009).

There are, basically, four risks arising from the production of pollutants in animal production environments: worker health, animal health, neighbor health, and deterioration of the facility and equipment (Nääs et al 2007). High concentrations of ammonia in broiler production facilities negatively influence the breeding environment, affecting animals and caretakers as well as locations close to these facilities (Medeiros et al 2005). In addition, ammonia is a highly corrosive compound that contributes to the deterioration of metal equipment and parts.

\section{Uric Acid}

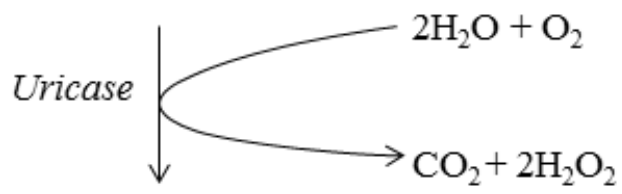

S-Allantoin

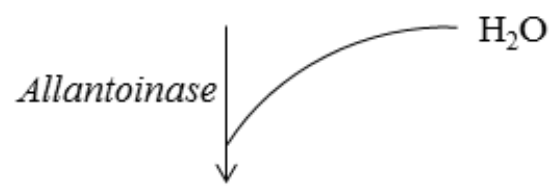

Allantoic Acid
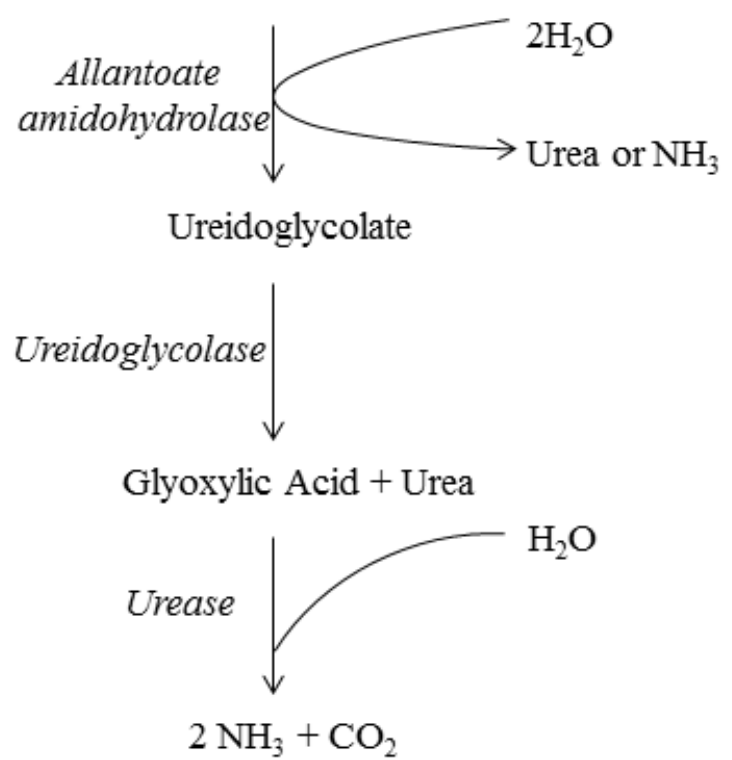

Figure 1 Stages of aerobic degradation of uric acid in ammonia. Adapted from Groot Koerkamp et al (1998).

Small particles, PM2.5, formed in the air by ammonia and other components, pose a health problem due to the impacts on the respiratory system. When inhaled, they can reach the lungs, and even short-term exposure can cause eye, nose, and throat irritation, in addition to coughing and sneezing. Long-term exposure can lead to a variety of respiratory and cardiovascular issues (Bittman and Mikkelsen 2009).

International standards for maximum ammonia concentration limits suggest that the concentration varies according to the period of exposure to the environment affected by ammonia; maximum limits are $25 \mathrm{ppm}$ for 8 hours, $35 \mathrm{ppm}$ for $15 \mathrm{~min}$, and $50 \mathrm{ppm}$ for $5 \mathrm{~min}$ (NIOSH 1988). The Brazilian legislation through the Ministry of Labor and Employment, according to Regulatory Norm NR15 (ABNT 1978), established the maximum limit of $20 \mathrm{ppm}$ of ammonia in work environments for a period of up to 48 hours per week. In the literature, $20 \mathrm{ppm}$ of ammonia are recommended as the maximum tolerable value for continuous exposure in an animal production environment (Wathes et al 1997).

The harmful effect on the health of animals and workers exposed to ammonia depends on both the concentration and the exposure period. Typically, people working in poultry production facilities tend to have a high incidence of various acute and chronic symptoms, including coughing, eye irritation, fatigue, nasal congestion, sneezing, headache, throat irritation, and fever (Donham 2000; Perry 2003).

Elevated levels of $\mathrm{NH}_{3}$ in the premises can generate production losses by reducing feed efficiency and growth rates; excessive occurrence of certain particles can cause stress, affecting the immune system and generating vulnerability to diseases, thereby decreasing the productive performance of animals and workers (Osório et al 2009).

Ideally, ammonia levels are kept below a concentration of $25 \mathrm{ppm}$. Although the maximum acceptable limit of ammonia concentration is $20 \mathrm{ppm}$, but a maximum level of $10 \mathrm{ppm}$ should always be the objective (Groot Koerkamp et al 1998).

Exposure to ammonia impairs weight gain (Equation 1), feed efficiency or conversion (Equation 2), and viability (Equation 3) in the production of broilers, as it affects the average weight and feed intake and, for several reasons, can cause the death of the birds before the end of the productive cycle. In facilities with ammonia levels of $25 \mathrm{ppm}$ during the entire growth period, a significant reduction of the final body weight was observed in the broilers produced, with an average total weight loss of $90 \mathrm{~g}$ per bird (Lott and Donald 2005; Miles et al 2004).

Continuous exposure to an ammonia-saturated environment, even at low levels, causes irritation of the respiratory mucosa of birds, increasing susceptibility to respiratory diseases. In humans, continuous exposure even to low ammonia levels can cause eye and lung irritations (Gay and Knowlton 2009). High levels of $\mathrm{NH}_{3}$ in the premises can result in production losses by reducing feed efficiency and growth rates (Oliveira et al 2003). 
Excess ammonia in the environment can also cause various disorders and problems in animals, such as reduced appetite and respiratory rates, burns and calluses on the cushions of the feet, skin irritations, calluses in the chest, eye irritation, conjunctivitis, blindness, respiratory system issues, weight loss, low uniformity, and susceptibility to viral diseases and infections, thereby significantly decreasing productivity (Osório et al 2009).

\section{Weight gain $=$ Final body weight $(\mathrm{kg})-$ Initial body weight $(\mathrm{kg}) \quad$ Equation 1}

\section{Feed efficiency $=\frac{\text { Feed intake }(\mathrm{kg})}{\text { Total of broilers produced }(\mathrm{kg})} \quad$ Equation 2}

\section{Viability $=$ percentage of live broilers at the end of cycle}

Equation 3
Signs of lesions from ammonia intoxication vary according to the age of the bird, the degree of exposure, and the concentration of the gas. Prolonged exposure to high concentrations of ammonia, such as 50 to $100 \mathrm{ppm}$, decreases production due to the incidence of increased lacrimal secretion, catarrhal tracheitis, keratoconjunctivitis, and photophobia, which may result in more serious problems such as blindness (Egute et al 2010).

Ammonia emitted in concentrations higher than 60 ppm within animal production facilities leaves birds more susceptible to respiratory diseases, predisposing them to risks of infections secondary to vaccinations (Oliveira et al 2004; Rocha et al 2014). In extreme cases, when concentrations reach $100 \mathrm{ppm}$, immediate reduction of the respiratory rate can be the result, which leads to death even under short-term exposure (Groot Koerkamp et al 1998).

Table 1 shows the relationship between ammonia concentrations and the main effects on humans and animals.

Economic losses generated by the emission of pollutants

Exposure to ammonia, pollutants, and aerial microorganisms significantly affects the growth of broilers, favors susceptibility to disease, reduces food consumption, alters feed conversion and growth rate, and increases mortality. Gas emissions in the production of broilers negatively influence the production environment and the surrounding region, causing considerable economic and financial losses (Medeiros et al 2008). High ammonia emissions can lead to weight losses of up to 250 grams per bird by current weight standards, with continuous exposure at 25 ppm levels, indicating losses of 90 grams per bird, and increased condemnation of carcasses to 500 birds per productive lot (Lott and Donald 2005).

Even when exposure only occurs in the first weeks of breeding, the birds show significant weight reductions at the end of the production cycle (Miles et al 2004).

In terms of financial losses resulting from high levels of ammonia in a shed with 20,000 birds with an ammonia concentration of $50 \mathrm{ppm}$, losses amount to around US\$ 450.00 relative to weight losses of birds, about US\$ 700.00 relative to the ration, because the increase of $8 \%$ in feed conversion, an average of US\$ 160 with diseases and US\$ 150 with condemnation of carcasses (Lott and Donald 2005; Ritz et al 2005). In a previous study about broiler production environments, ammonia reductions of $10 \%$ resulted in a final weight increase (at 42 days) of more than 45 grams (Miles et al 2004). Adequate management practices and efficient control of ammonia emissions may represent significant differences between profit and loss for producers; the costbenefit ratio of ammonia control is favorable when weight loss and increased feed efficiency are accounted for (Lott and Donald 2005; Ritz et al 2005).

Gas emissions and environmental damage

In addition to ammonia, animal production facilities also emit a number of potent greenhouse gases (GEEs), mainly carbon dioxide $\left(\mathrm{CO}_{2}\right)$, methane $\left(\mathrm{CH}_{4}\right)$, and nitrous oxide $\left(\mathrm{N}_{2} \mathrm{O}\right)$ (Fabbri et al 2007). Nitrous oxide is produced in the processes of nitrification and denitrification of the waste, and degrades the ozone layer in the stratosphere, contributing to global warming (Calvet et al 2011). Their global warming potentials were set by the Intergovernmental Panel on Climate Change (IPCC 2006) as $20\left(\mathrm{CH}_{4}\right)$ and $300\left(\mathrm{~N}_{2} \mathrm{O}\right)$ times the potential of carbon dioxide $\left(\mathrm{CO}_{2}\right)$. Significant increases in atmospheric ammonia emissions in intensive animal production areas have been reported in recent years (Gay and Knowlton 2009). It is estimated that agriculture is responsible for $85 \%$ of the volatilization of ammonia in the United States; of this, an estimated $30 \%$ were emitted by broiler production facilities in the year 2015 (EPA 2004).

Ammonia emissions from animal production are not restricted to the production facility and significantly impact the environment, mainly by acidification and eutrophication of water bodies (Gates et al 2008). In addition, groundwater contamination can occur when chicken litter is used excessively as fertilizer and the contained nitrates leach into 
the soil. Nitrates are mobile when soluble in water and can therefore be rapidly transported through the soil, reaching the ground water and contaminating drinking water supplies (Bittman and Mikkelsen 2009; Oviedo-Rondón 2008).
This review emphasizes the need of significantly reducing $\mathrm{NH}_{3}$ levels in animal production facilities as a crucial step to maintain both the health of workers and animals in these environments, in addition to avoid potential environmental degradation (Kim and Patterson 2003).

Table1 Different ammonia concentrations and the impacts on human and animal health

\begin{tabular}{|c|c|c|}
\hline $\begin{array}{l}\text { Concentration } \\
\text { (ppm) }\end{array}$ & Humans & Animals \\
\hline 5 & $\begin{array}{c}\text { Presence of ammonia can be detected by some people by the } \\
\text { odor }\end{array}$ & \\
\hline 10 & Most people can easily detect the presence of ammonia by odor & \\
\hline 20 & Environmentally unhealthy environment (NR-15) & Initial discomfort \\
\hline $20-25$ & & $\begin{array}{l}\text { Maximum tolerable amount for birds at long-term } \\
\text { exposure }\end{array}$ \\
\hline 30 & $\begin{array}{l}\text { Respiratory system issues, including coughing, salivary } \\
\text { secretion, phlegm presence, and even urine retention }\end{array}$ & \\
\hline $35-40$ & & $\begin{array}{c}\text { Maximum tolerable amount for birds at short-term } \\
\text { exposure }\end{array}$ \\
\hline 50 & Acute eye irritation & Acute eye irritation \\
\hline 80 & & Reduced food consumption and growth \\
\hline 100 & Eye burns, temporary blindness, and skin irritation may occur & $\begin{array}{c}\text { Drastic reduction of respiratory rate, consumption, } \\
\text { growth }\end{array}$ \\
\hline 500 & $\begin{array}{l}\text { Violent attack of cough, severe irritation in the lungs, pulmonary } \\
\text { edema, can lead to death }\end{array}$ & Lethal dose \\
\hline
\end{tabular}

Source: Adapted from Perry (2003).

\section{Final Considerations}

Ammonia as well as other polluting gases produced in broiler breeding environments, even in countries located in warm-weather regions where facilities are predominantly open, potentially damage human and animal health, thereby affecting productivity and resulting in economic losses. In addition, negative impacts on the environment are inevitable.

The efficient control of ammonia emissions through adequate management practices can represent a significant difference between profit and loss for producers, since the cost-benefit ratio of ammonia control is favorable when losses are accounted for increases in food efficiency, in addition to promoting the production of sustainable food, both in terms of preservation of the environment as well as the sustainability of low-cost food production.

\section{Acknowledgements}

The authors are grateful to the follows Brazilian foundations: Coordenação de Aperfeiçoamento de Pessoal de Nível Superior (CAPES), Conselho Nacional de Desenvolvimento Científico e Tecnológico (CNPq) and
Fundação de Amparo à Pesquisa do Estado de Minas Gerais (FAPEMIG).

\section{References}

ABNT (1978) Associação Brasileira de Normas Técnicas. NR-15: Atividades e Operações Insalubres. Portaria Ministério do Trabalho, Brasília, 85 p.

Angus AJ, Hodge ID, Sutton MA (2006) Ammonia abatement strategies in livestock production: A case study of a poultry installation. Agricultural Systems 89:204-222.

Bittman S, Mikkelsen R (2009) Ammonia Emissions from Agricultural Operations: Livestock. Better Crops 93:28-31.

Calvet S, Cambra-López M, Estellés F, Torres AG (2011) Characterization of gas emissions from a Mediterranean broiler farm. Poultry science 90:534-542.

Donham K (2000) A historical overview of research on the hazards of dust in livestock buildings. In Dust Control in Animal Production Facilities, Proc. Congress in Aarhus, Denmark, 2000. Horsens, Denmark: Danish Institute of Agricultural Sciences, Research Centre Bygholm, 1:13-21.

Egute NS, Abrao A, Carvalho FMS (2010) Estudo do processo da geração de amônia a partir de resíduos avícolas visando a produção de hidrogênio. Revista Brasileira de Pesquisa e Desenvolvimento $12: 1-6$.

EPA (2004) National emission inventory-ammonia emissions 
from animal husbandry operations (Draft Report). United States Environmental Protection Agency, n. January 30:D1-D16.

Fabbri C, Valli L, Guarino M, Costa A, Mazzotta V (2007) Ammonia, methane, nitrous oxide and particulate matter emissions from two different buildings for laying hens. Biosystems Engineering 97:441-455.

Faulkner WB, Shaw BW (2008) Review of ammonia emission factors for United States animal agriculture. Atmospheric Environment 42:6567-6574.

França LGF, Tinoco IFF (2014) Caracterização de fatores que influenciam a emissão de amônia pelos dejetos de galinhas poedeiras e proposição de um score para o potencial máximo de emissão. In: XLIII Congresso Brasileiro de Engenharia Agrícola. Proceedings... Campo Grande: CONBEA 2014.

Gates RS, Casey KD, Wheeler EF, Xin H, Pescatore AJ (2008) U.S. broiler housing ammonia emissions inventory. Atmospheric Environment 42:3342-3350.

Gay SW, Knowlton KF (2009) Ammonia emissions and animal agriculture Virginia Cooperative Extension. Virginia Cooperative Extension. Virginia State, Petesburg, 110:442-445.

Groot Koerkamp PWG, Metz JHM, Uenk GH, Phillips VR, Holden MR, Sneath RW, Short JL, White RP, Hartung J, Seedorf J, Schroder M, Linkert KH, Pedersen S, Takai H, Johnsen JO, Wathes CM (1998) Concentrations and Emissions of Ammonia in Livestock Buildings in Northern Europe. Journal of Agricultural Engineering Research 70:79-95.

IPCC (2006) Emissions from livestock and manure management. In: IPCC Intergovernmental Panel On Climate (Ed.). Agriculture, Forestry and Other Land Use. Hayama, Kanagawa, Japan: Guidelines for National Greenhouse Gas Inventories 4:10.1-10.87.

Kim W, Patterson P (2003) Effect of minerals on activity of microbial uricase to reduce ammonia volatilization in poultry manure. Poultry Science 82:223-231.

Lott B, Donald J (2015) Amônia: Grandes perdas mesmo quando você não percebe. http://www.aviculturaindustrial.com.br/ Acessed in: march, 23 of 2015.

Marangoni C, Cichoski AJ, Barin JS, Menezes CR (2015) Efeito da incorporação de folhas de oliveira (Olea europaea L.) no desenvolvimento e qualidade da carne de frangos. Brazilian Journal of Food Technology 18:173-184.

Medeiros CM, Baêta FC, Oliveira RFM, Tinôco IFF, Albino LFT, Cecon PR (2005) Índice térmico ambiental de produtividade para frangos de corte. Revista Brasileira de Engenharia Agrícola e Ambiental 9:660-665.

Medeiros R, Santos BJM, Freitas M, Silva AO, Alves FF, Ferreira E (2008) A adição de diferentes produtos químicos e o efeito da umidade na volatilização de amônia em cama de frango. Ciência Rural 38:2321-2326.

Melse RW, Ogink NW, Rulkens M (2009) Overview of European and Netherlands' regulations on airborne emissions from intensive livestock production with a focus on the application of air scrubbers. Biosystems Engineering 104:289-298.

Mendes LB, Tinoco IFF, Ogink NWM, Rocha KSO, Saraz JAO, Santos MS (2014) Ammonia emissions from a naturally and a mechanically ventilated broiler house in Brazil. Revista Brasileira de Engenharia Agrícola e Ambiental 18:1179-1185.
Mendes LB, Edouard N, Ogink NWM, Van Dooren HJC, Tinõco IFF, Mosquera J (2015) Spatial variability of mixing ratios of ammonia and tracer gases in a naturally ventilated dairy cow barn. Biosystems Engineering 129:360-369.

Miles DM, Branton SL, Lott BD (2004) Atmospheric ammonia is detrimental to the performance of modern commercial broilers. Poultry Science 83:1650-1654.

Misselbrook TH, Van Der WTJ, Pain BF, (2000) Ammonia emission factors for UK agriculture. Atmospheric Environment 34:871-880.

Mosquera J, Monteny GJ, Erisman JW (2005) Overview and assessment of techniques to measure ammonia emissions from animal houses: the case of the Netherlands. Environmental Pollution 135:381-388.

Nääs IA, Miragliotta MY, Baracho MS, Moura DJ (2007) Ambiência aérea em alojamento de frangos de corte: poeira e gases. Engenharia Agrícola 27:326-335.

NIOSH (1988) OSHA PEL Project Documentation: AmmoniaNational Institute for Occupational Safety and Health. Centers for Disease Control and Prevention. Atlanta 1988:1-3.

Oliveira MC, Almeida CV, Andrade DO, Rodrigues SMM (2003) Teor de matéria seca, $\mathrm{pH}$ e amônia volatilizada da cama de frango tratada ou não com diferentes aditivos. Revista Brasileira de Zootecnia 32:951-954.

Oliveira MC, Ferreira HA, Cancherini LC (2004) Efeito de condicionadores químicos sobre a qualidade da cama de frango. Arquivo Brasileiro de Medicina Veterinária e Zootecnia 56:536541.

Osório JA, Tinôco IFF, Ciro HJ (2009) Ammonia: A review of concentration and emission models in livestock structures. Dyna 76:89-99.

Osorio-Saraz JA, Ferreira-Tinoco IF, Gates RS. Oliveira-Rocha KS, Combatt-Caballero EM, Campos-Sousa F (2014) Adaptation and validation of a methdology for determing ammonia flux generated by litter in naturally ventilated poultry houses. Dyna 81:137-143.

Oviedo-Rondón EO (2008) Tecnologias para mitigar o impacto ambiental da produção de frangos de corte. Revista Brasileira de Zootecnia 37:239-252.

Owada NA, Nääs IA, Moura DJ, Baracho MS (2007) Estimativa de bem-estar de frango de corte em função da concentração de amônia e grau de luminosidade no galpão de produção. Engenharia Agrícola 27:611-618.

Perry GC (2003) Welfare of the Laying Hen. World's Poultry Science Association 27:431.

Pessôa GBS, Tavernari FC, Vieira RV, Albino LFT (2012) Novos conceitos em nutrição de aves. Revista Brasileira de Saúde e Produção Animal 13:755-774.

Ritz CW, Fairchild BD, Lacy MP (2005) Litter Quality and Broiler Performance. Cooperative Extension Service/The University of Georgia College of Agricultural and Environmental Sciences 1267:1-8.

Rocha TM, Andrade MA, Santana ES, Fayad AR, Matias TD (2014) Aspectos clínicos, patológicos e epidemiológicos de doenças imunossupressoras em aves. Enciclopédia Biosfera 10:355-379.

Saraz JAO, Tinôco IFF, Gates RS, Paula MO, Mendes LB (2013) Evaluation of different methods for determining ammonia 
emissions in poultry buildings and their applicability to open facilities. Dyna 80:51-60.

Scholtens R, Dore CJ, Jones BMR, Lee DS, Phillips VR (2004) Measuring ammonia emission rates from livestock buildings and manure stores - Part 1: Development and validation of external tracer ratio, internal tracer ratio and passive flux sampling methods. Atmospheric Environment 38:3003-3015.

Silva YL, Rodrigues PB, Freitas RTF, Bertechini AG, Fialho ET, Fassani EJ, Pereira CR (2006) Redução de proteína e fósforo em rações com fitase para frangos de corte no período de 1 a 21 dias de idade. Desempenho e teores de minerais na cama. Revista Brasileira de Zootecnia 35:840-848.

Tinôco IFF (2001) Avicultura industrial: novos conceitos de materiais, concepções e técnicas construtivas disponíveis para galpões avícolas brasileiros. Revista Brasileira de Ciência Avícola $3: 1-24$.

Wathes CM, Holden MR, Sneath RW, White RP, Phillips VR (1997) Concentrations and emissions rates of aerial ammonia, nitrous-oxide, carbon-dioxide, dust and endotoxin in UK broiler and layer houses. British Poultry Science 38:14-28. 